\title{
Magnesium: Engineering the Surface
}

\author{
X. B. CHEN ${ }^{1}$ H. Y. YANG,${ }^{1,2}$ T. B. ABBOTT, ${ }^{1,3}$ M. A. EASTON ${ }^{1}$ \\ and N. BIRBILIS ${ }^{1,4}$ \\ 1.-CAST Co-operative Research Centre and the Department of Materials Engineering, Monash \\ University, Clayton, VIC 3800, Australia. 2.-National Engineering Research Center of Light \\ Alloy Net Forming and State Key Laboratory of Metal Matrix Composites, Shanghai Jiaotong \\ University, Shanghai, People's Republic of China. 3.-Advanced Magnesium Technologies, \\ Sydney, NSW, Australia. 4.-e-mail: nick.birbilis@monash.edu
}

\begin{abstract}
Magnesium $(\mathrm{Mg})$ and its alloys provide numerous benefits as lightweight materials; however, industrial deployment of $\mathrm{Mg}$ in most instances requires anticorrosion coatings. Engineering the $\mathrm{Mg}$ surface is an area that has been undergoing intense research recently. Surface engineering commences with the "pretreatment" step, which can be used to modify the surface composition and morphology, resulting in surface enrichment or depletion of alloying elements. Following this, electrochemical plating (including electro- and electroless plating) and conversion coatings have emerged as common means of coating $\mathrm{Mg}$. In this study, we present the key aspects relating to the science and technology associated with pretreatment, electrochemical plating, and conversion coatings. This is followed by experimental examples of engineered surfaces of industrial relevance.
\end{abstract}

\section{INTRODUCTION}

Magnesium ( $\mathrm{Mg}$ ) and its alloys are highly susceptible to aqueous corrosion in near-neutral conditions. Upon atmospheric exposure, $\mathrm{Mg}$ rapidly develops porous, poorly bonded, and inhomogeneous oxide/hydroxide/carbonate films ${ }^{1}$ which do not provide satisfactory corrosion protection. As such, surface modification and/or surface coatings are necessarily applied upon $\mathrm{Mg}$ alloys, ${ }^{2}$ being an effective means to improve corrosion resistance and isolate the base material from the environment. Electrochemical plating ${ }^{3}$ and chemical conversion coating $^{4}$ are two typical, comparatively low-cost, and easily implemented methods that have been widely adopted in industrial processes. In this paper, we briefly review these two technologies, follow the review with a discussion of the role of coating pretreatment, and then present some experimental results.

\section{ELECTROCHEMICAL PLATING}

Electrochemical plating can produce metallic coatings with solderability, electrical conductivity, and decorative appearance, in addition to corrosion and wear resistance. Such coatings are nominally subdivided into two groups: electroplating and electroless plating. Electroplating (often termed electrodeposition) is a plating process that employs an electrical signal provided by an external power source to reduce cations of a desired metal in solution and produce a metallic coating. Electroless plating is a "self-reduction" process, relying on a process of autocatalytic reduction of metal ions in aqueous solution containing a chemical reducing agent (typically sodium hypophosphite, $\mathrm{NaH}_{2} \mathrm{PO}_{2}$ ). At present, electroless Ni-P plating coating is the main electroless process. As the name implies, no external power source is required. Electroplating can yield a thicker and more compact metal coating compared with electroless plating. The pros and cons of these methods are: thinner electroless coatings may have micro-pinholes, which must be subsequently sealed; however, uneven current distribution during electroplating is a challenge for coating components with complex shapes (while electroless plating is a good solution to this). Depending on the service conditions and shape of the components, these two plating methods can be applied separately or in combination to $\mathrm{Mg}$ alloys. In fact, a hallmark more typical of coating $\mathrm{Mg}$ than any other system is that the final coated products have usually undergone several coating steps (i.e., 
have multilayered coatings). Conventionally, multilayered metal coatings such as $\mathrm{Cu} / \mathrm{Ni} / \mathrm{Cr}$ are deposited on preplated $\mathrm{Mg}$ samples for outdoor use, e.g., automotive applications. Noble metals such as $\mathrm{Ni} / \mathrm{Au}$ multilayers on $\mathrm{Mg}$ have been explored for aerospace applications. ${ }^{2}$ Electroless Ni-P coating after sealing is mainly used in mildly aggressive conditions, such as in the computer and electronic (3C) industries.

\section{CONVERSION COATING}

In the conversion coating process, the substrate to be protected is immersed in a solution that reacts with the surface, altering the metal ion concentration and the $\mathrm{pH}$ at the metal-solution interface. ${ }^{5-7}$ This process relies on "corrosion" of the substrate to produce metal ions, where the localized change in composition causes precipitation from the solution onto the surface of the substrate to form the coating. ${ }^{5-7}$ The composition of the base $\mathrm{Mg}$ alloy, the pretreatment processes, the composition of the conversion formulations, posttreatments, and operational parameters, such as temperature, $\mathrm{pH}^{8}$ immersion duration, and degree of agitation, ${ }^{6}$ can all influence the structure, composition, and anticorrosion performance of conversion coatings. A uniform coating with defect-free features is desirable to fulfill its protective role.

Conventional chromate $\left(\mathrm{Cr}^{6+}\right)$ conversion coatings, though recognized as an effective means of protecting reactive metals (including $\mathrm{Mg}$ ), have now been banned in many countries due to pollution and safety concerns. ${ }^{2,4}$ Numerous efforts have been made to invent a conversion coating comparable in performance to or better than chromate, such as phosphate/phosphate-manganese, ${ }^{9,10}$ stannate, ${ }^{11-13}$ fluoride ${ }^{14}$ rare earth (RE) ${ }^{15-17}$ hydrotalcite, ${ }^{7}$ ionic liquid, ${ }^{18}$ molten salt, ${ }^{19}$ vanadium, ${ }^{20}$ stearic acid, ${ }^{21}$ etc., but each case has its own disadvantages. Stannate, RE, ionic liquid, and molten salt conversion coatings are not applicable for practical use at this stage, due to either the high cost of raw materials or long coating duration; fluoride and vanadium-based coatings still have toxicity issues, and stearic acid coatings require high operational temperatures. Calcium phosphate conversion coatings are noteworthy for their simplicity in operation, low cost, and low environmental impact. ${ }^{2,4}$ In existing reports ${ }^{6}$ the formation of calcium phosphate coatings led to an improvement in corrosion resistance relative to untreated alloy, revealing a promising candidate for good corrosion resistance.

\section{PRETREATMENT}

In regards to $\mathrm{Mg}$ coatings, there is a requirement that they must be uniform, adherent, and pore-free, otherwise rapid corrosion occurs due to loss of the barrier effect (it being prudent at this point to emphasize that $\mathrm{Mg}$ coatings provide a barrier effect, and not active anodic protection, such as galvanizing does to steel, since no practical anodic coatings for $\mathrm{Mg}$ exist owing to $\mathrm{Mg}$ being so reactive itself). ${ }^{2-4}$ To achieve this, one of the most difficult and critical aspects is to develop an appropriate pretreatment process; this is the necessary precursor to all coating steps and hence requires special attention with regards to engineering the surface. Once a suitably presented alloy surface can be realized, many desired coatings can be readily achieved. ${ }^{2}$ It is not trivial to plate protective coatings onto $\mathrm{Mg}$ alloys. Because of the low solubility of most metals in $\mathrm{Mg}$ (but the requirement of alloying to achieve strength), an electrochemically heterogeneous surface of alloy surfaces exists (for example, such as for AZ91D, Fig. 1), such that each component behaves differently in the plating bath, leading to nonuniform coating growth. Consequently, pretreatment is a key step to coating $\mathrm{Mg}$, mainly including the following steps in no specific order: mechanical pretreatment, acid activation/ pickling, and alkaline cleaning/conditioning.

Regarding electro- and electroless plating techniques, undercoating is also essential prior to plating, to improve adhesion and reduce galvanic corrosion between metal coatings and the $\mathrm{Mg}$ substrate. $^{22-24}$ So far, two types of undercoatings: $\mathrm{Zn}$ immersion followed by pre-electroplating $(\mathrm{Cu}, \mathrm{Zn}$ or $\mathrm{Ni}$ or $\mathrm{Ni} / \mathrm{Cu}$ or $\mathrm{Zn} / \mathrm{Cu}$ ) and $\mathrm{Ni}$ by electroless plating, are used for subsequent electroplating. ${ }^{2}$ Once a suitable undercoating is successfully plated on substrates of $\mathrm{Mg}$ alloys, many other metals with desired properties can be electrodeposited (we present a relevant example below).

Using AZ91D as the principal example, the typical conversion coating process is as simple as immersion in appropriate chemicals, and can be preceded by any number of pretreatment steps to aid in optimization of the coating (final step). Pretreatments must necessarily impart some sort of functionality by modification of the alloy surface. The microstructural impact (phenomenologically) of

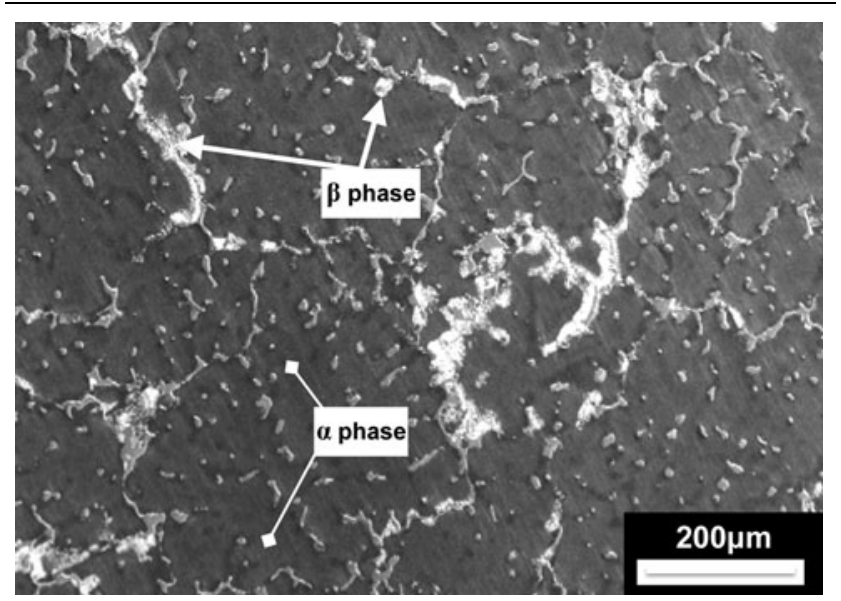

Fig. 1. Backscattered electron micrograph of AZ91D (as polished) revealing two-phase structure. 


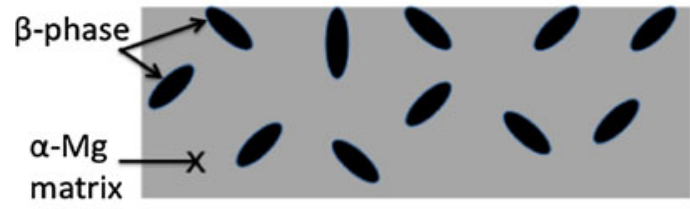

(a)

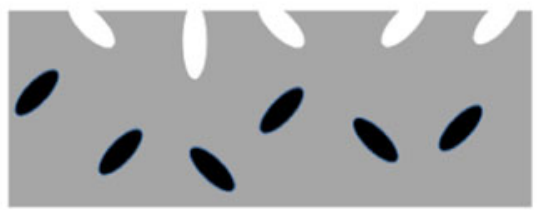

(c)

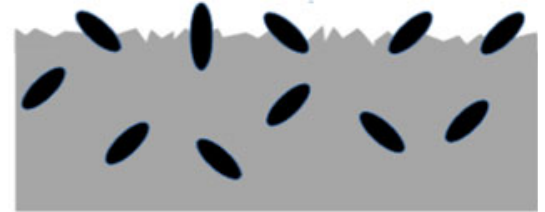

(b)

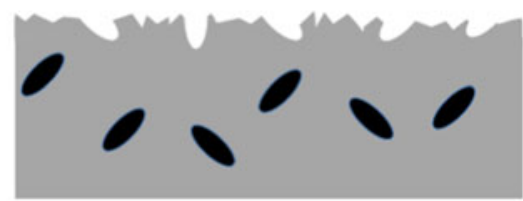

(d)

Fig. 2. Schematic representation of AZ91D surface (in section view) following the various pretreatment processes: (a) as polished, (b) activator treated, (c) conditioner treated, and (d) activator + conditioner treated.

the most common pretreatment procedures is shown in Fig. 2 for AZ91D. "Activator" pretreatment (the common term given to acid treatment) is shown to attack the $\mathrm{Mg}$ matrix but leave the $\beta$-phase essentially unaffected. In the case of "conditioner" pretreatment (the common term given to alkaline treatment), the opposite is true, whereby $\beta$-phase is preferentially removed (since the Al-containing phase dissolves at high $\mathrm{pH}$, whereas the matrix is essentially unaffected, since $\mathrm{Mg}$ is passive in alkaline conditions). ${ }^{25}$ As a result, the careful selection, or even combination of, activator and conditioner treatments allows one to clean, degrease, functionalize, and homogenize the surface of an alloy prior to ultimate coating.

\section{EXPERIMENTAL PROCEDURES}

\section{Material Preparation and Coatings}

In this work, samples of AZ91D [Mg-9.02Al$0.49 \mathrm{Zn}$, wt.\% as measured by inductively coupled plasma-atomic emission spectroscopy (ICP-AES)] from alloy supplier HNKWE (Henan Province, China) were used. A Toshiba 250-ton clamping force cold chamber high-pressure die casting (HPDC) machine was used to cast test plates of $70 \mathrm{~mm} \times$ $60 \mathrm{~mm} \times 2 \mathrm{~mm}$ in size. $\mathrm{SiC}$ paper (1200 grit) was used to remove traces of die spray and the as-cast surface layers from samples.

For coatings, rather than present the whole range of chemicals used in pretreatment and coatings here, the details are presented with the relevant information in the relevant sections. Generally, however, pretreatment was executed prior to conversion coating, electroless plating, or $\mathrm{Zn}$ immersion (which is a post-pretreatment step and precursor to electrodeposited coatings). Electrodeposition of $\mathrm{Zn}$ was further performed on Zn-immersion-treated AZ91D. In cases where electroplating was performed, the rear of specimens was drilled and tapped so that a wire for electrical connection could be attached, and specimens were then mounted with an appropriate resin, exposing a free surface to be electroplated.

\section{Characterization}

Electrochemical tests were conducted using a flat cell (PAR) with electrode area of $1 \mathrm{~cm}^{2}$. The reference electrode used was a saturated calomel electrode (SCE), and the counterelectrode was Ti mesh. A Biologic ${ }^{\circledR}$ VMP-3Z potentiostat was used to execute potentiodynamic polarization measurements at sweep rate of $1 \mathrm{mV} / \mathrm{s}$. Scanning electron microscopy (SEM) was carried out using an FEI Nova Nano and Jeol 7001F.

\section{EXPERIMENTAL EXAMPLES OF COATING SYSTEMS}

It is not possible, in one manuscript, to give a holistic description and demonstration of the range of coatings available. Therefore, some selected examples are given to emphasize the function and importance of pretreatments, electrochemical coatings, and conversion coatings.

\section{Conversion Coatings}

Pretreatment is a critical step in the development of suitably performing coatings, and was recently shown to be as important, if not more important, than the final coating itself. ${ }^{2,4}$ Pretreatments in the case of conversion coatings can serve several purposes, but are principally used to homogenize the surface in order to minimize local galvanic cell activity. The classic example is pretreatment of AZ91D as depicted in Fig. 3. What is seen is that, following activation [in $10 \mathrm{~g} / \mathrm{L}$ sodium nitrate $\left(\mathrm{NaNO}_{3}\right)$ and $1 \mathrm{~mL} / \mathrm{L}$ phosphoric acid $\left(\mathrm{H}_{3} \mathrm{PO}_{4}\right)$ solution at room temperature for $2 \mathrm{~min}$ ], surface roughness increases dramatically and the apparent density of $\beta$-phase is increased owing to surface recession of the $\alpha$-matrix. The extent to which this 


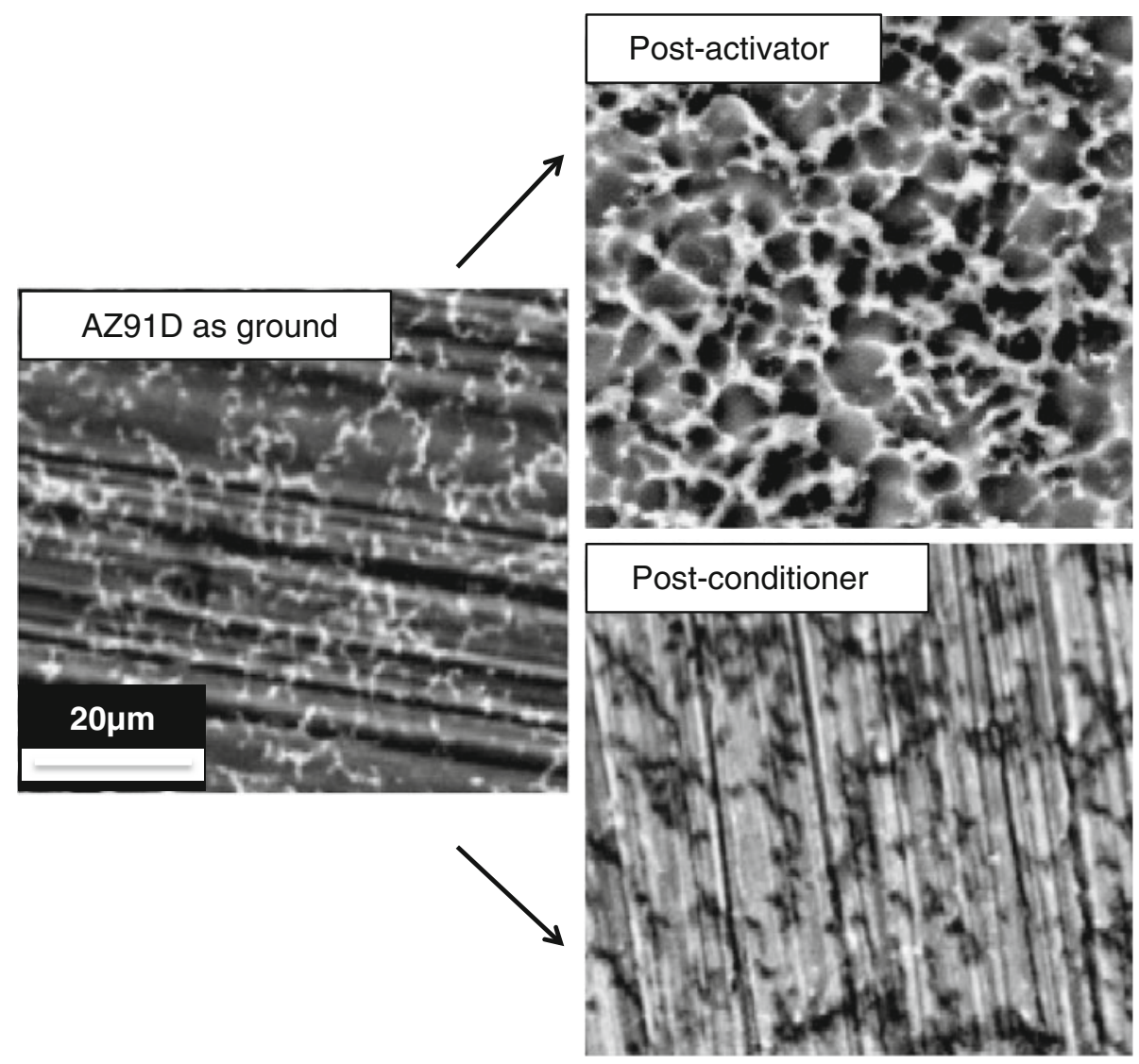

Fig. 3. Backscattered electron micrographs of AZ91D following activation and conditioning as compared with the as-ground condition.

occurs can be regulated by the selection of temperature, time, and chemistry $/ \mathrm{pH}$ of the activator bath. Conversely, following conditioning [in $200 \mathrm{~g} / \mathrm{L}$ sodium hydroxide $(\mathrm{NaOH})$ at $70^{\circ} \mathrm{C}$ for $\left.5 \mathrm{~min}\right]$, we can observe (Fig. 3) selective dissolution of $\beta$-phase, leaving cavities. The combination of activation and conditioning is effective to remove the $\beta$-phase. We emphasize that failure to homogenize and pretreat the surface renders the subsequent conversion coating defective (and hence ineffective) owing to failure to coat $\beta$-phase particles, since the chemical conversion process is restricted to sites of high metal ion activity such as the $\alpha$-matrix.

Regarding conversion coatings for AZ91D, recent focus has been on calcium phosphate coatings, which have shown appreciable corrosion resistance ${ }^{5},{ }^{26}$ owing to the formation of the $\mathrm{CaHPO}_{4} \cdot 2 \mathrm{H}_{2} \mathrm{O}$ compound on the surface, and also the possibility to be posttreated to stimulate precipitation of hydroxyapatite $\left[\mathrm{Ca}_{5}\left(\mathrm{PO}_{4}\right)_{3}(\mathrm{OH})\right]{ }^{5}$ The latter displays good chemical stability and inertness in neutral/service conditions.

The final conversion coating (following the aforementioned activation and conditioning) is $2.36 \mathrm{~g} / \mathrm{L}$ $\mathrm{Ca}\left(\mathrm{NO}_{3}\right)_{2} \cdot 4 \mathrm{H}_{2} \mathrm{O}$ and $0.82 \mathrm{~g} / \mathrm{L} \mathrm{Na}_{3} \mathrm{PO}_{4} . \mathrm{Ca}^{2+}$ ions were added in the form of calcium nitrate tetrahydrate, and sodium phosphate was used as source of $\mathrm{PO}_{4}{ }^{3-}$ ions. The $\mathrm{pH}$ of the coating solutions was adjusted to

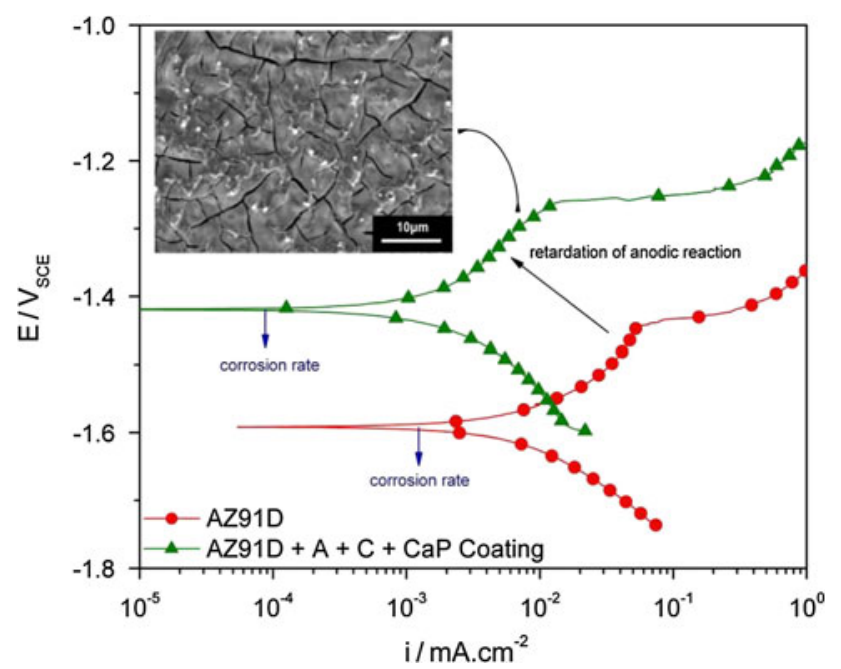

Fig. 4. Potentiodynamic polarization curves in $0.1 \mathrm{M} \mathrm{NaCl}$ for AZ91D and AZ91D + activator, conditioner, and calcium phosphate conversion coating. Inset: backscattered electron micrograph of conversion-coated specimen.

$\mathrm{pH} 3.0$ using nitric acid $\left(\mathrm{HNO}_{3}\right)$ with conversion coating carried out at $40^{\circ} \mathrm{C}$ for 5 min. Digital temperature controllers were used to maintain the bath temperature. We observe from Fig. 4 that the calcium phosphate coating (SEM image inset, showing 
the coating presence and subsequent dehydration cracking under vacuum conditions) gives a significant shift in the anodic reaction kinetics on AZ91, and as such can reduce the corrosion rate whilst ennobling the potential.

\section{ELECTROCHEMICAL COATINGS}

In the case of electrochemical coatings, again, pretreatment is crucial prior to plating. ${ }^{2}$ Herein, we show the effect of pretreatment on the two main two types of undercoatings for subsequent electroplating: (1) electroless $\mathrm{Ni}$, and (2) $\mathrm{Zn}$ immersion followed by pre-electroplating (again $\mathrm{Zn}$ ). To avoid confusing readers who may be new to Mg coatings, we emphasize that final electroplated coatings on $\mathrm{Mg}$ are not produced directly upon $\mathrm{Mg}$ alloy surfaces. This is because the Mg surface itself is not suitable for electrodeposition of most metals, since it is not capable of sustaining reduction reactions, viz. coating deposition, at sufficient rates.

Typically, following chemical pretreatment, preplating is also executed, the most common being $\mathrm{Zn}$ immersion to form a Zn-rich layer on the $\mathrm{Mg}$ surface, and then preplating $\mathrm{Cu}$ to form a $\mathrm{Cu}$-rich layer on the Zn layer (also enhancing the reduction reaction rate upon the surface for final electrodeposition). Nowadays, however, preplating $\mathrm{Zn}$ is intensively studied as a green alternative to preplating $\mathrm{Cu}$ (from cyanide-containing baths).

Historically, chromium compounds and fluoride have been used as pickling pretreatment of $\mathrm{Mg}$ alloys prior to commencement of electroplating steps. As such, we present some results comparing this process (which is progressively being restricted due to toxicity) as compared with a more environmentally friendly pretreatment. Following alkaline degreasing/ conditioning $\left(60 \mathrm{~g} / \mathrm{L} \mathrm{NaOH}+10 \mathrm{~g} / \mathrm{L} \mathrm{Na}_{3} \mathrm{PO}_{4} \cdot 12 \mathrm{H}_{2} \mathrm{O}\right.$, $\left.80^{\circ} \mathrm{C}, 10 \mathrm{~min}\right), \mathrm{AZ91D}$ was immersed in a $\mathrm{HNO}_{3}+$ $\mathrm{CrO}_{3}$ pickling solution and $\mathrm{HF}$ activated $(125 \mathrm{~g} / \mathrm{L}$ $\mathrm{CrO}_{3}+110 \mathrm{~mL} / \mathrm{L} \mathrm{HNO}_{3}$, room temperature, $30 \mathrm{~s}$; $385 \mathrm{~mL} / \mathrm{L} 40 \% \mathrm{HF}$, room temperature, $8 \mathrm{~min}$ ), producing the surface shown in Fig. 5a. This treatment partially dissolves the matrix and preferentially etches the boundary between $\alpha$ and $\beta$ phase, resulting in high surface roughness. In contrast, following conditioning and pickling $\left(30 \mathrm{~g} / \mathrm{L} 85 \% \mathrm{H}_{3} \mathrm{PO}_{4}+100 \mathrm{~g} / \mathrm{L}\right.$ $\mathrm{Na}_{3} \mathrm{PO}_{4} \cdot 12 \mathrm{H}_{2} \mathrm{O}+20 \mathrm{~g} / \mathrm{L} \mathrm{KMnO}_{4}$, room temperature, $5 \mathrm{~min}$ ), the surface is relatively smooth and it is impossible to clearly distinguish the $\alpha$ and $\beta$ phases
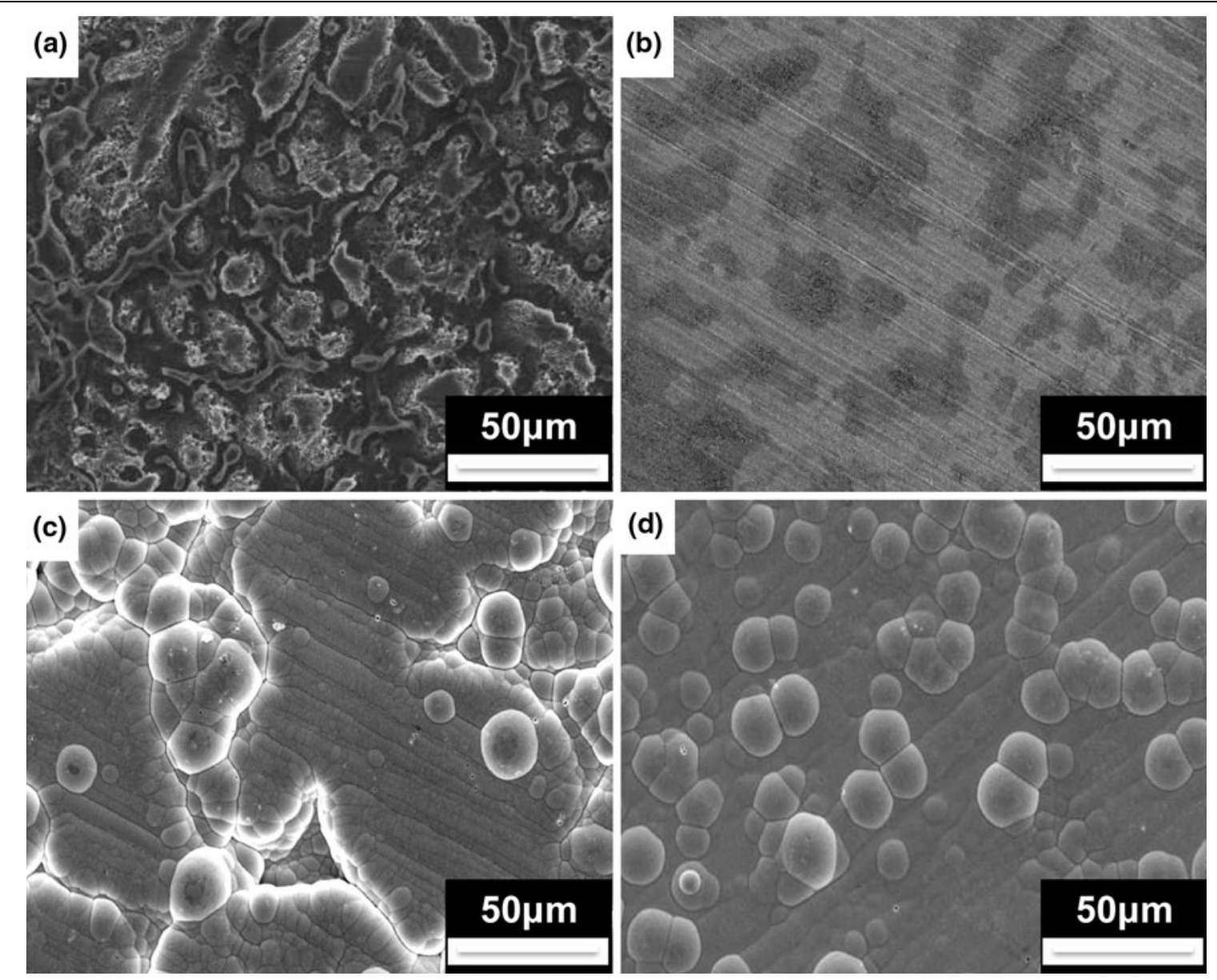

Fig. 5. Backscattered electron micrographs showing surfaces following: (a) $\mathrm{CrO}_{3}+\mathrm{HNO}_{3}$ pretreatment, (b) $\mathrm{H}_{3} \mathrm{PO}_{4}$ pretreatment, (c) treatment as in (a) followed by electroless NiP coating, and (d) treatment as in (b) followed by electroless Ni-P coating (full chemical details given in text). 
(Fig. 5b). The prevalence and characterization of very thin films on the surface that result from pickling are not described herein for the sake of brevity; however, their existence has already been documented. ${ }^{27}$

Following the above pretreatments, electroless $\mathrm{Ni}-\mathrm{P}$ plating $\left(15 \mathrm{~g} / \mathrm{L} \mathrm{NiSO}_{4} \cdot 6 \mathrm{H}_{2} \mathrm{O}, 4.8 \mathrm{~g} / \mathrm{L} \mathrm{NaH}_{2}\right.$ $\mathrm{PO}_{2} \cdot \mathrm{H}_{2} \mathrm{O}, 22 \mathrm{~g} / \mathrm{L} \quad \mathrm{C}_{6} \mathrm{H}_{8} \mathrm{O}_{7} \cdot \mathrm{H}_{2} \mathrm{O}, \quad 8.5 \mathrm{~g} / \mathrm{L} \quad \mathrm{NH}_{4} \mathrm{HF}$, $9 \mathrm{~mL} / \mathrm{L} 40 \% \mathrm{HF}, \mathrm{pH}$ adjusted to 6 by $\mathrm{NH}_{4} \mathrm{OH}, 80^{\circ} \mathrm{C}$, $30 \mathrm{~min}$ ) was applied to the specimens (Fig. 5c, d). The purpose of this comparison is to reveal that, depending on the pretreatment applied, the Ni-P

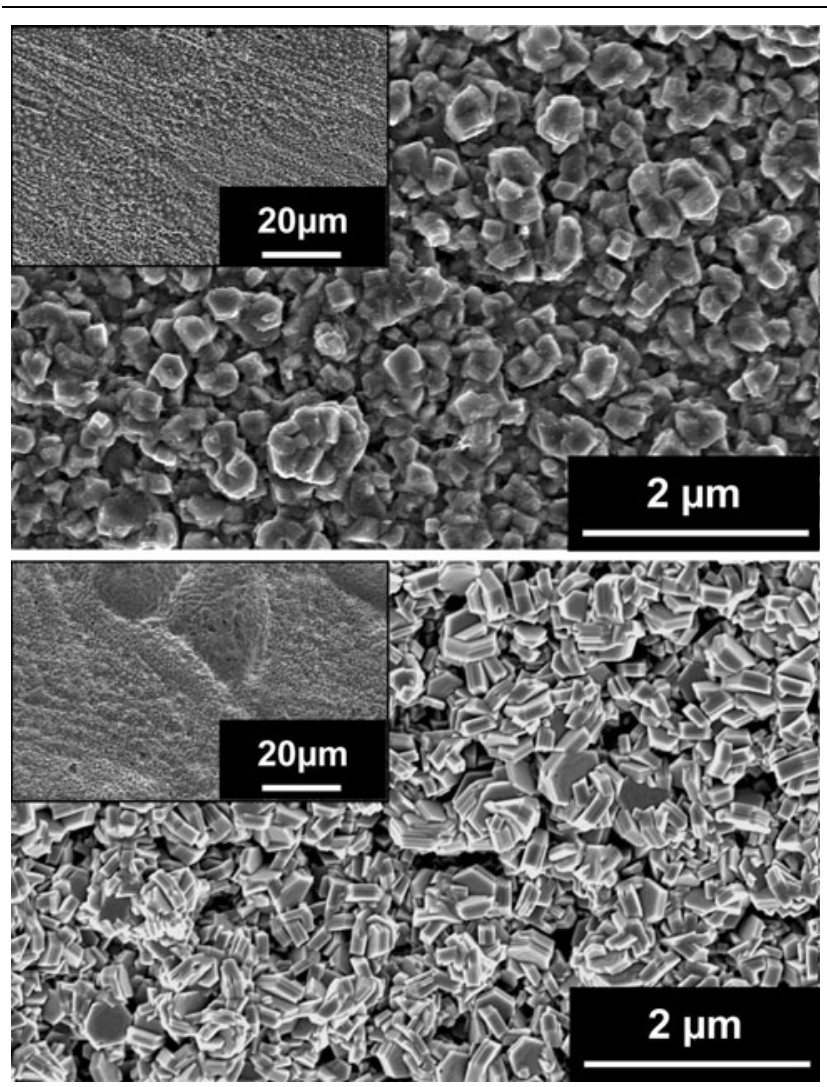

Fig. 6. Morphology of surface of AZ91D following $\mathrm{Zn}$ immersion for a (top) $\mathrm{H}_{3} \mathrm{PO}_{4}$ pretreated sample, and (bottom) $\mathrm{H}_{3} \mathrm{PO}_{4}+\mathrm{Na}_{2} \mathrm{Mo}_{4}$ (+HF-activated) pretreated sample. morphology will differ significantly. Electroless Ni-P coating on AZ91D pretreated by the $\mathrm{H}_{3} \mathrm{PO}_{4}$ process shows a more uniform and dense surface film which could also be used as a good undercoating for subsequent plating. This example also shows that the scope and number of potential pretreatments are large, and indeed semi-infinite, making pretreatment optimization an area of vigorous present and future research.

To give a different example related to $\mathrm{Zn}$ immersion, the role of two different pretreatments is again presented. $\mathrm{Zn}$ immersion was performed in $50 \mathrm{~g} / \mathrm{L}$ $\mathrm{ZnSO}_{4} \cdot 7 \mathrm{H}_{2} \mathrm{O}+150 \mathrm{~g} / \mathrm{L} \quad \mathrm{K}_{2} \mathrm{P}_{2} \mathrm{O}_{7} \cdot 3 \mathrm{H}_{2} \mathrm{O}+7 \mathrm{~g} / \mathrm{L} \quad \mathrm{KF} \cdot$ $2 \mathrm{H}_{2} \mathrm{O}+6 \mathrm{~g} / \mathrm{L} \mathrm{Na}_{2} \mathrm{CO}_{3}\left(80^{\circ} \mathrm{C}, 5 \mathrm{~min}\right)$. The specimens immersed were AZ91D that was conditioned and pickled in $30 \mathrm{~g} / \mathrm{L} 85 \% \mathrm{H}_{3} \mathrm{PO}_{4}+100 \mathrm{~g} / \mathrm{L} \quad \mathrm{Na}_{3} \mathrm{PO}_{4}$. $12 \mathrm{H}_{2} \mathrm{O}+20 \mathrm{~g} / \mathrm{L} \mathrm{KMnO}_{4}$ (room temperature, $5 \mathrm{~min}$ ) and also AZ91D pretreated in $200 \mathrm{~mL} / \mathrm{L} 85 \%$ $\mathrm{H}_{3} \mathrm{PO}_{4}+1 \mathrm{~g} / \mathrm{L} \mathrm{Na} \mathrm{Mo}_{4} \cdot 2 \mathrm{H}_{2} \mathrm{O}\left(45^{\circ} \mathrm{C}, 15 \mathrm{~s}\right), 80 \mathrm{~g} / \mathrm{L}$ $\mathrm{Na}_{4} \mathrm{P}_{2} \mathrm{O}_{7}, 20 \mathrm{~g} / \mathrm{L} \quad \mathrm{Na}_{2} \mathrm{CO}_{3}, 30 \mathrm{~g} / \mathrm{L} \mathrm{NaNO}_{3}\left(80^{\circ} \mathrm{C}\right.$, $10 \mathrm{~min}$ ), and $385 \mathrm{~mL} / \mathrm{L} 40 \% \mathrm{HF}$ (room temperature, $8 \mathrm{~min}$ ). The whole surface of AZ91D treated by either of the above processes was covered by a $\mathrm{Zn}$ immersion film (Fig. 6). However, a much more compact $\mathrm{Zn}$ immersion film was formed on AZ91D after being treated by the $\mathrm{H}_{3} \mathrm{PO}_{4}$ process (Fig. 6, top), again showing the key role of pretreatment.

To take an example through to completion in the case of electrodeposited coatings, the specimen from Fig. 6 (top) was electrodeposited with a zinc coating. Electrodeposition of $\mathrm{Zn}$ (which was itself the counterelectrode material) was performed in $10 \mathrm{~g} / \mathrm{L}$ $\mathrm{ZnO}+120 \mathrm{~g} / \mathrm{L} \mathrm{KOH}+20 \mathrm{~g} / \mathrm{L} \mathrm{KF}$ (room temperature, $30 \mathrm{~min}, 80 \mathrm{~mA} / \mathrm{cm}^{2}$ ). A metallic $\mathrm{Zn}$ coating can be plated very well on AZ91D, provided the critical pretreatment and undercoating have been executed, as shown in Fig. 7. The $\mathrm{Zn}$ coating consists of nanoparticles with size $\sim 25 \mathrm{~nm}$. The cross-section shows that the $\mathrm{Zn}$ coating is compact and homogeneous over the substrate.

Figure 8 presents the potentiodynamic polarization response of AZ91D, AZ91D with a Zn immersion film, and AZ91D with electroplated Zn (above a zinc
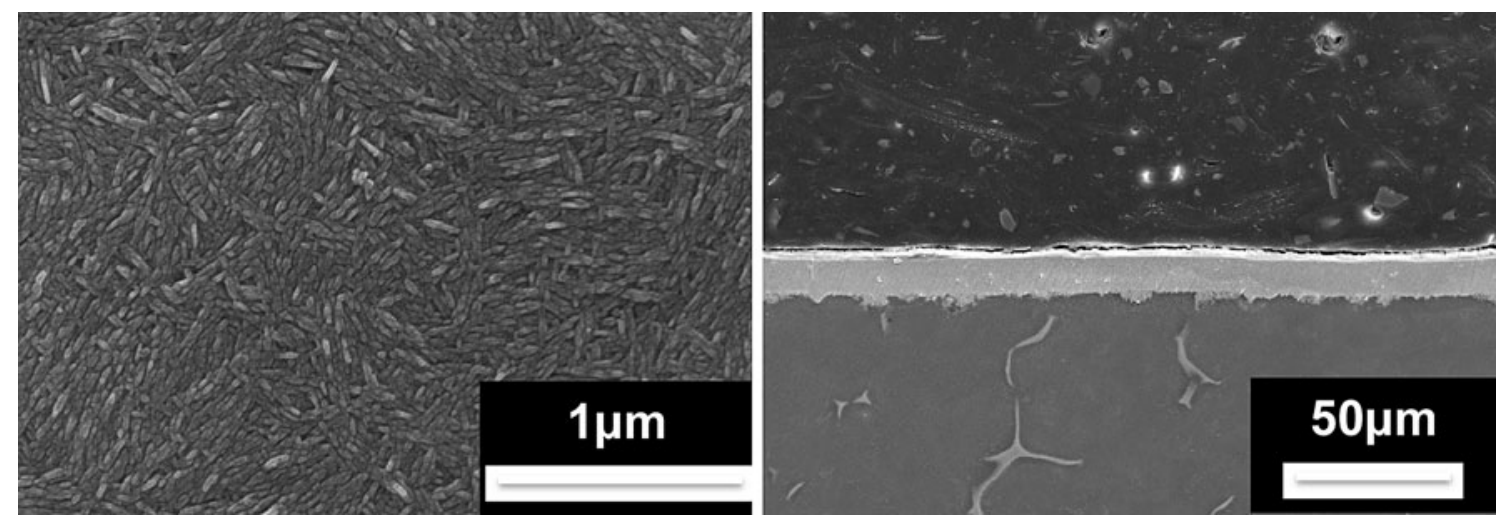

Fig. 7. Left: view from above of the surface of Zn-electrodeposited AZ91D pretreated, then Zn-immersion treated; right: cross-sectional view of specimen on left, where the uniform and defect-free nature of the coating is evident. 


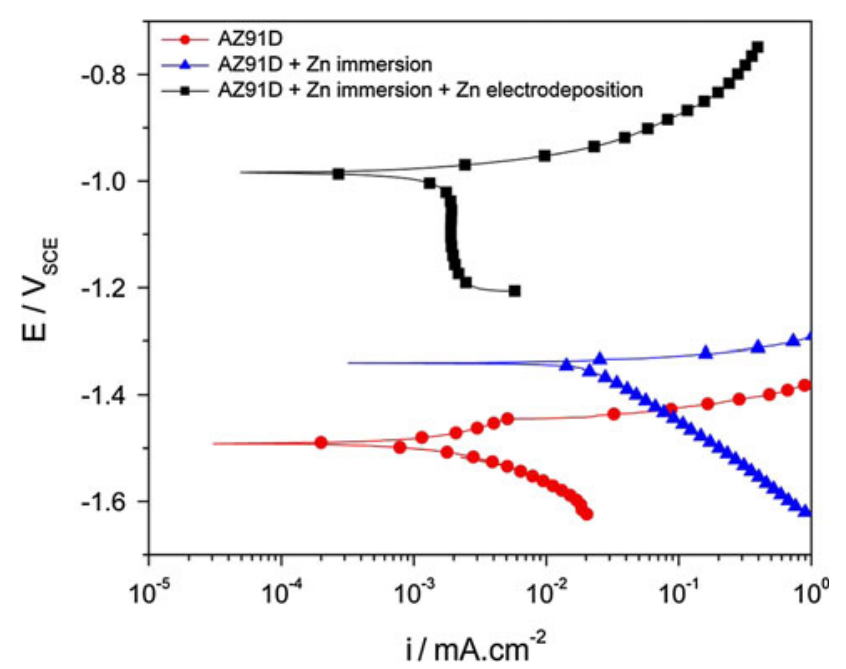

Fig. 8. Potentiodynamic polarization curves in $0.1 \mathrm{M} \mathrm{NaCl}$ for AZ91D, AZ91D following Zn immersion (which followed the $\mathrm{H}_{3} \mathrm{PO}_{4}$ pretreatment), and AZ91D following $\mathrm{Zn}$ immersion and $\mathrm{Zn}$ electrodeposition.

immersion film) for the specimen in Fig. 7. Following $\mathrm{Zn}$ immersion, the corrosion potential is ennobled; however, the corrosion rate is enhanced (owing in part to the enhanced cathodic activity of $\mathrm{Zn}$ ), indicating that the Zn-immersion film is not an effective protective coating for the substrate. Following electrodeposition, the corrosion potential is further ennobled and the corrosion rate decreased after electrodeposition of the $\mathrm{Zn}$ coating, since the complete $\mathrm{Zn}$ coverage retards anodic dissolution and renders the sample behavior to be that of $\mathrm{Zn}$ and not $\mathrm{Mg}$.

\section{CONCLUSIONS}

Herein, the key aspects relating to the science and technology associated with pretreatments, electrochemical plating, and conversion coatings are described, albeit in a quick overview manner, followed by examples of engineered surfaces of industrial relevance. The chemical composition of the conversion coating/plating bath plays a critical role in their anticorrosion performance; however, it was shown that the coating performance also heavily relies on appropriate pretreatments to functionalize the surface. Developing better, simpler, cheaper, and environmentally friendly coating technologies is and will remain a hot topic needing further investigation, likely to be fuelled by the advantages of the weight reduction that $\mathrm{Mg}$ can provide when fully exploited in practical applications.

\section{ACKNOWLEDGEMENTS}

The CAST CRC was established under, and is funded in part by, the Australian Commonwealth Government Cooperative Research Centre scheme. H.Y.Y. and N.B. thank the CSC Scheme (China).

\section{REFERENCES}

1. M. Santamaria, F.D. Quarto, S. Zanna, and P. Marcus, Electrochim. Acta 53, 1314 (2007).

2. J.E. Gray and B. Luan, J. Alloy. Compd. 336, 88 (2002).

3. X.-B. Chen, H.-Y. Yang, T.B. Abbott, M.A. Easton, and N. Birbilis, Corrosion 68, 518 (2012).

4. X.-B. Chen, N. Birbilis, and T.B. Abbott, Corrosion 67, 035005 (2011).

5. X.-B. Chen, T. Abbott, and N. Birbilis, Corros. Sci. 53, 2263 (2011).

6. Y. Song, D. Shan, R. Chen, F. Zhang, and E.-H. Han, Corros. Sci. 51, 62 (2009).

7. J.K. Lin and J.Y. Uan, Corros. Sci. 51, 1181 (2009).

8. C.S. Lin, H.C. Lin, K.M. Lin, and W.C. Lai, Corros. Sci. 48, 93 (2006).

9. Y. Song, D. Shan, R. Chen, F. Zhang, and E.-H. Han, Surf. Coat. Technol. 203, 1107 (2009).

10. W.Q. Zhou, D.Y. Shan, E.H. Han, and W. Ke. Preparation Method of Magnesium Alloy Chromeless Chemical Conversion Film and its Used Film Forming Solution. CN1475602A, 02-18, 2004.

11. H. Huo, Y. Li, and F. Wang, Corros. Sci. 46, 1467 (2004).

12. H.H. Elsentriecy, K. Azumi, and H. Konno, Electrochim. Acta 53, 4267 (2008).

13. F. Zucchi, A. Frignani, V. Grassi, G. Trabanelli, and C. Monticelli, Corros. Sci. 49, 4542 (2007).

14. K.Y. Chiu, M.H. Wong, F.T. Cheng, and H.C. Man, Surf. Coat. Technol. 202, 590 (2007).

15. H. Ardelean, I. Frateur, and P. Marcus, Corros. Sci. 50, 1907 (2008).

16. C. Wang, S.L. Zhu, F. Jiang, and F.H. Wang, Corros. Sci. 51, 2916 (2009).

17. M.F. Montemor, A.M. Simões, and M.J. Carmezim, Appl. Surf. Sci. 253, 6922 (2007).

18. N. Birbilis, P.C. Howlett, D.R. MacFarlane, and M. Forsyth, Surf. Coat. Technol. 201, 4496 (2007).

19. M.F. He, L. Liu, Y.T. Wu, Z.X. Tang, and W.B. Hu, Corros. Sci. 50, 3267 (2008).

20. K.H. Yang, M.D. Ger, W.H. Hwu, Y. Sung, and Y.C. Liu, Mater. Chem. Phys. 101, 480 (2007).

21. X.P. Lei, G. Yu, Y.P. Zhu, Z.P. Zhang, X.M. He, B.N. Hu, and Y. Chen, Trans. Inst. Metal Finishing 88, 75 (2010).

22. J.-W. Tang and K. Azumi, Surf. Coat. Technol. 205, 3050 (2011).

23. Y.-F. Jiang, C.-Q. Zhai, L.-F. Liu, Y.-P. Zhu, and W.-J. Ding, Surf. Coat. Technol. 191, 393 (2005).

24. C.-D. Gu, J.-S. Lian, J.-G. He, Z.-H. Jiang, and Q. Jiang, Surf. Coat. Technol. 200, 5413 (2006).

25. M. Pourbaix, Atlas of Electrochemical Equilibria in Aqueous Solutions, 2nd ed. (Houston, TX: National Association of Corrosion Engineers (NACE), 1974).

26. X.-B. Chen, T. Abbott, and N. Birbilis, Corros. Sci. 55, 226 (2012).

27. H.-Y. Yang, X.-B. Chen, X.W. Guo, G.H. Wu, W.J. Ding, and N. Birbilis, Appl. Surf. Sci. 258, 5472 (2012). 